\title{
Staining techniques for detection of acid fast bacilli: what hope does fluorescein-diacetate (FDA) vitality staining technique represent for the monitoring of tuberculosis treatment in resource limited settings
}

\author{
Zingue Dezemon ${ }^{1 *}$, Claude Mambo Muvunyi ${ }^{2,3}$ and Otu Jacob ${ }^{4}$ \\ ${ }^{*}$ Correspondence: zinguedezemon@yahoo.fr

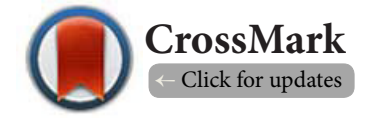 \\ ${ }^{1}$ Centre MURAZ research institute, Burkina Faso. \\ ${ }^{2}$ National Reference Laboratory, Biomedical Service Department, Rwanda Biomedical Center, Rwanda. \\ ${ }^{3}$ College of Medicine and Health Science, University of Rwanda, Rwanda. \\ ${ }^{4}$ Molecular Microbiology and Mycobacteriology Laboratories, Medical Research Council Unit, The Gambia.
}

\begin{abstract}
Despite the recent development of more sensitive technologies, diagnosis of tuberculosis in resource limited settings continues to rely on sputum smear microscopy. This is explained by the fact that smear microscopy is simple, inexpensive, and the most accessible tool in resource limited settings for tuberculosis diagnosis. Hot Ziehl-Neelsen (Z-N) is still used in laboratories of resource limited settings with bright field microscopy. Cold staining methods which use bright field microscopy are now declared obsolete. Currently in most laboratories, methods of staining using fluorescence microscopy (FM) and Light-emitting diodes (LED) microscopy for Acid Fast Bacilli (AFB) are used. Despite the accessibility of Z-N method, only 15 of the 22 high tuberculosis burden countries met the target of having one microscopy centre per 100, 000 persons in 2011 . This review attempts to provide an overview description of microscopy methods as well as the Fluorescein-diacetate (FDA) vitality staining methods as alternative for culture and tuberculosis treatment control in resource limited countries.
\end{abstract}

Keywords: Tuberculosis, ziehl-neelsen, light-emitting diodes, fluorescein-diacetate, resource limited settings

\section{Introduction}

Tuberculosis (TB) remains a global emergency health problem in 21 st century [1,2], mainly affecting people in sub-Saharan Africa [3]. It is an infectious and transmissible disease caused by Mycobacterium tuberculosis complex [4]. These bacteria are known as tubercle bacilli because they produce characteristic lesions called tubercles [5]. About 10\% of infected individuals develop TB in their lifetime $[4,6,7]$. Untreated TB cases infect 10 to 15 people every year $[1,2]$. Today, HIV infection is the major risk factor for developing TB disease in individuals with latent tuberculosis infection [8]. Acid-fast bacilli (AFB) can be identified with Ziehl-Neelsen (Z-N) staining method in resourcelimited settings [9-12]. Despite the recent development of more sensitive technologies, diagnosis of TB in most low-income countries continues to rely on sputum smear microscopy [2] due to the fact that smear microscopy is a simple, inexpensive, cost-effective, and accessible tool for pulmonary TB diagnosis

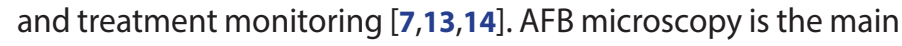
technique used in Directly Observed Therapy short course (DOTS) programs for diagnosis of TB, follow-up treatment, and curative services for tuberculosis $[1,15]$. Z-N microscopy is highly specific, but its overall sensitivity is variable (20-80\%)
$[1,9,16]$. Smear sensitivity is poor in extra-pulmonary TB, in diseases caused by mycobacterium other than tuberculosis (MOTT), and in HIV-infected TB patients $[7,15]$. There are two microscopic systems used to detect AFB in the sputum (ordinary and fluorescence microscopy) and various staining techniques. Importantly, smear microscopy cannot distinguish viable from dead bacilli in smear. Microscopic detection of mycobacterium does not distinguish also M. tuberculosis complex from MOTT [4]. Culture can distinguish viable and non-viable bacilli of expectoration but, its used is very limited in resource limited settings because this method requires safety equipment, containment laboratories, and trained personnel. Improved tuberculosis case detection and enlarged capacity for the detection of drug resistance are global priorities for tuberculosis control in resource limited settings. The development and implementation of FDA staining method could be a useful strategy and alternative to culture methods for TB treatment in resource limited settings.

\section{Review \\ Sputum smear microscopy}

The most important tool in the diagnosis of TB is direct micro- 
scopic examination of appropriately stained sputum specimens for AFB in resource limited settings when used in a wellventilated TB laboratory with restricted access [17]. Laboratory examination of sputum by direct acid-fast smear has been the most rapid and cost-effective method to detect infectious cases of TB for approximately 125 years. National Tuberculosis Program (NTP) defined a smear-positive case of pulmonary tuberculosis as a tuberculosis suspect with two positive sputum specimens [15]. The revised definition is based on the presence of at least one AFB positive in at least one sputum sample in countries with a well-functioning external quality. AFB positive smears retained the primary stain when the smear is decolorized with an acid-alcohol solution [18]. AFB-microscopy needs 5,000 to 10,000 AFB per milliliter of sputum for direct microscopy to be positive $[7,15,19]$ (Figure 1). Only $60 \%$ of the smears are positive if $10^{6} \mathrm{AFB}$ per $\mathrm{ml}$ are present in the sputum. Sputum smear microscopy detects most infectious cases and specificity is very high (97-99\%) in settings where the burden of TB is high $[\mathbf{2 0}, \mathbf{2 1}]$. The workload is cumbersome when dealing with a large number of patients. Smear preparation, staining, and examination must be supported by adequate internal quality control and external quality assessment system.

There are two procedures commonly used for acid-fast staining, Carbolfuchsin methods which include Ziehl-Neelsen, and Fluorochrome procedure using auramine-O or auraminerhodamine dyes. Fluorescence microscopy has a 10\% higher sensitivity and equivalent specificity to ordinary microscopy [22]. These acid-fast staining techniques and other different procedures of AFB staining techniques are described in Table 1.

\section{Old and obsolete staining methods}

These methods are not frequently used in major laboratories in resource limited settings. Young researchers who are curious to know these methods could experiment to improve on them.

\section{Kinyoun cold staining method}

Kinyoun uses the same reagents as the conventional ZiehlNeelsen method that permits the cold staining of tubercle bacilli by increasing the staining time as shown in Table 1 $[14,23]$. For direct smears, the correlation of the results of the cold staining procedure to Ziehl-Neelsen method was $97 \%$ and $99 \%$ respectively [23]. Application in the field is inferior to hot Z-N [24].

\section{Gabett's cold staining method}

In the Gabbet's staining method, methylene blue acts as decolourizer and counter stain. It has been advocated as an alternative staining technique. Procedure for Gabbet's cold staining method is carried out as described in Table 1 [25].

\section{Tan thiam hok staining method}

This method was developed in 1962. The staining technique combines the cold saturated primary stain with the Gabett's

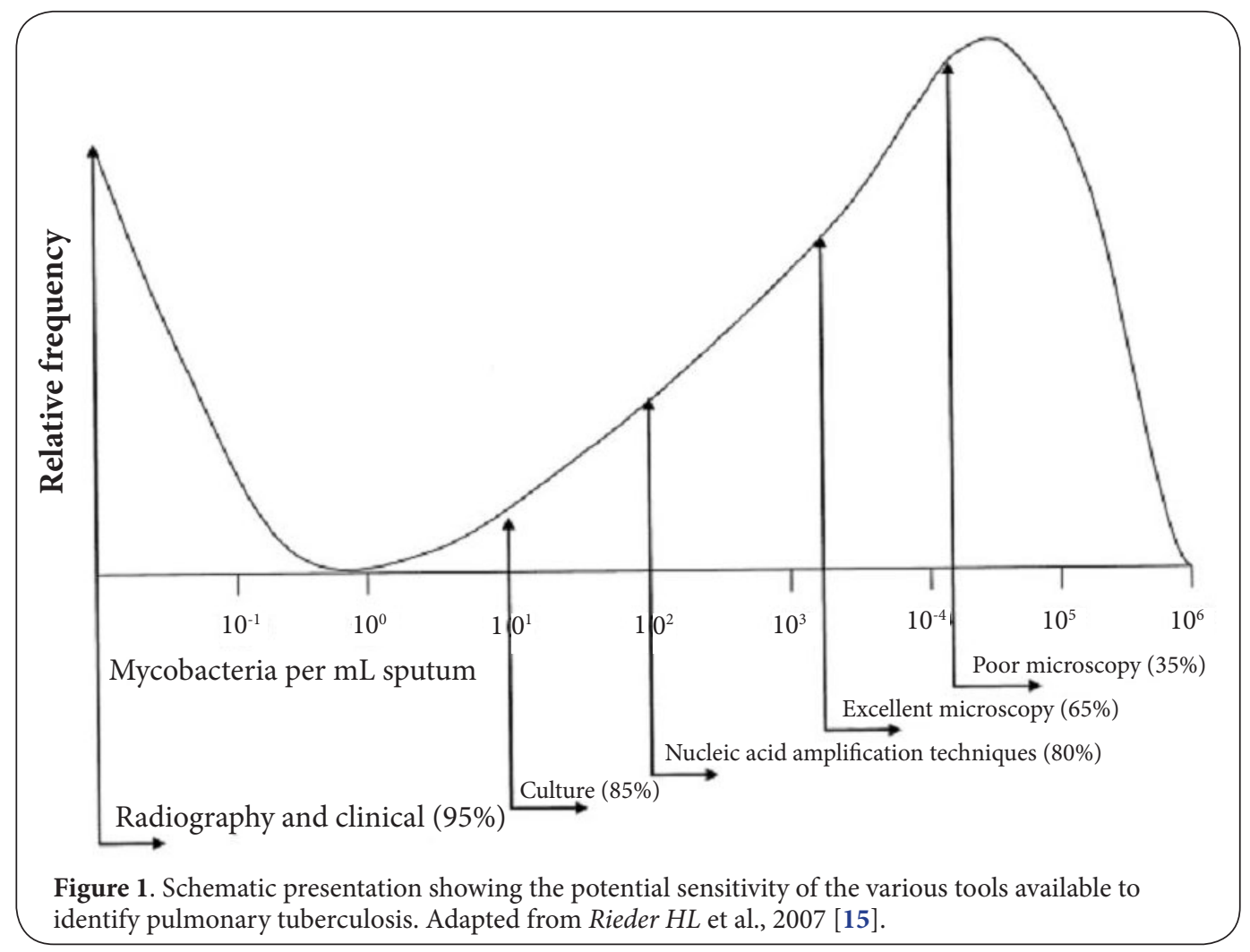


Dezemon et al. Trends in Bacteriology 2014,

http://www.hoajonline.com/journals/pdf/2057-4711-1-1.pdf

doi: $10.7243 / 2057-4711-1-1$

Table 1. Staining procedures.

\begin{tabular}{|c|c|c|c|c|c|c|}
\hline $\begin{array}{l}\text { Hot Ziehl-Neelsen } \\
\text { staining }\end{array}$ & Kinyoun cold staining & $\begin{array}{l}\text { Tan Thiam Hok } \\
\text { staining }\end{array}$ & Gabett's staining & $\begin{array}{l}\text { Fluorescence microscopy } \\
\text { (auramine staining) }\end{array}$ & $\begin{array}{l}\text { LED Fluorescence } \\
\text { microscopy (auramine) }\end{array}$ & $\begin{array}{l}\text { Fluorescein-diacetate } \\
\text { (FDA) staining/LED }\end{array}$ \\
\hline $\begin{array}{l}\text { Heat-fixe smears on } \\
\text { microscope slides }\end{array}$ & $\begin{array}{l}\text { Heat-fixe smears on } \\
\text { microscope slides }\end{array}$ & $\begin{array}{l}\text { Air dry and heat } \\
\text { fixe smears }\end{array}$ & $\begin{array}{l}\text { Air dried smears } \\
\text { but not heat fixed }\end{array}$ & $\begin{array}{l}\text { Air dry and heat fixe } \\
\text { smears }\end{array}$ & $\begin{array}{l}\text { Air dry and heat fixe } \\
\text { smears }\end{array}$ & $\begin{array}{l}\text { Air dry and heat fixe } \\
\text { smears }\end{array}$ \\
\hline \multicolumn{7}{|c|}{ Place the slides in Laboratory Serial Number (LSN) on the leveled staining bridge and smear side up } \\
\hline $\begin{array}{l}\text { Cover the whole surface } \\
\text { of the slides with } 0.3 \% \\
\text { Carbol fuchsin }\end{array}$ & $\begin{array}{l}\text { Flood with basic } 3.3 \% \\
\text { fuchsin-phenol stain }\end{array}$ & $\begin{array}{l}\text { Cover the plate } \\
\text { with Kinyoun } \\
\text { solution }\end{array}$ & $\begin{array}{l}\text { Flood Smears with } \\
1 \% \text { basic fuchsin } \\
\text { phenol solution }\end{array}$ & $\begin{array}{l}\text { Flood the slides with } \\
\text { freshly filtered auramine- } \\
\text { phenol solution }\end{array}$ & $\begin{array}{l}\text { Flood with } 0,1 \% \\
\text { auramine-phenol } \\
\text { solution }\end{array}$ & $\begin{array}{l}\text { Staining unfixed smears } \\
\text { with FDA working } \\
\text { solution }(0,025 \%)\end{array}$ \\
\hline $\begin{array}{l}\text { Heat gently until vapor } \\
\text { rises }\end{array}$ & Do not heat & Do not heat & Do not heat & Do not heat & Do not heat & Do not heat \\
\hline $\begin{array}{l}\text { Leave the warm stain } \\
\text { for at least } 5 \text { minutes at } \\
\text { room temperature }\end{array}$ & $\begin{array}{l}\text { Leave for } 5 \text { minutes at } \\
\text { room temperature }\end{array}$ & $\begin{array}{l}\text { leave in contact } \\
\text { for } 3 \text { minutes }\end{array}$ & $\begin{array}{l}\text { Leave for } 10 \\
\text { minutes at room } \\
\text { temperature }\end{array}$ & Leave for 20 minutes & Leave for 20 minutes & Leave for $30 \mathrm{~min}$ at $37^{\circ} \mathrm{C}$ \\
\hline $\begin{array}{l}\text { Rinse each slide gently } \\
\text { with clean water until all } \\
\text { macroscopically visible } \\
\text { stain has been washed } \\
\text { away }\end{array}$ & $\begin{array}{l}\text { Wash the smears in } \\
\text { running water. }\end{array}$ & $\begin{array}{l}\text { Wash with water } \\
\text { for } 30 \text { seconds }\end{array}$ & $\begin{array}{l}\text { Wash the smear } \\
\text { with the tap water }\end{array}$ & $\begin{array}{l}\text { Wash smears with tap } \\
\text { water }\end{array}$ & $\begin{array}{l}\text { Wash gently in running } \\
\text { water and drain }\end{array}$ & $\begin{array}{l}\text { Wash gently in running } \\
\text { water and drain }\end{array}$ \\
\hline $\begin{array}{l}\text { Cover slides with the } \\
\text { decolorizing solution } \\
\text { (25\% sulfuric acid or } 3 \% \\
\text { acid-alcohol) }\end{array}$ & $\begin{array}{l}\text { Cover slides with the de- } \\
\text { colorizing solution ( } 3 \% \\
\text { acid-alcohol solution) }\end{array}$ & -- & -- & $\begin{array}{l}\text { Cover the slides well with } \\
0.5 \% \text { acid alcohol solution }\end{array}$ & $\begin{array}{l}\text { Decolorize with } 0.5 \% \\
\text { acid-alcohol }\end{array}$ & $\begin{array}{l}\text { Distaining with } 0.5 \% \\
\text { acid alcohol }\end{array}$ \\
\hline Leave for 3 minutes & Leave for 2 minutes & -- & -- & $\begin{array}{l}\text { Allow to act for } 2-3 \\
\text { minutes }\end{array}$ & Leave for 3 minutes & Leave for $3 \mathrm{~min}$ \\
\hline $\begin{array}{l}\text { Rinse with clean water; } \\
\text { Then tilt the slides }\end{array}$ & $\begin{array}{l}\text { Rinse with clean water } \\
\text { and air-dry }\end{array}$ & -- & -- & $\begin{array}{l}\text { Rinse the slides with clean } \\
\text { water }\end{array}$ & $\begin{array}{l}\text { Wash gently in running } \\
\text { water and drain }\end{array}$ & $\begin{array}{l}\text { Wash gently in running } \\
\text { water }\end{array}$ \\
\hline $\begin{array}{l}\text { Flood smears with } \\
\text { methylene blue solution }\end{array}$ & $\begin{array}{l}\text { Counterstained with } \\
\text { Gabbet's methylene blue }\end{array}$ & $\begin{array}{l}\text { Cover the plate } \\
\text { with Gabett } \\
\text { solution }\end{array}$ & $\begin{array}{l}\text { counterstained } \\
\text { with Gabbet's } \\
\text { methylene blue }\end{array}$ & $\begin{array}{l}\text { Counterstained with } 0.1 \% \\
\text { KMno4 }\end{array}$ & $\begin{array}{l}\text { counter stain with } 0.5 \% \\
\text { KMno4 }\end{array}$ & $\begin{array}{l}\text { Quenching with } 0.5 \% \\
\text { KMnO4 }\end{array}$ \\
\hline Leave for 1 minute & Leave for 1 minute & $\begin{array}{l}\text { leave in contact } \\
\text { for } 1 \text { minute }\end{array}$ & $\begin{array}{l}\text { Leave for } 2 \\
\text { minutes }\end{array}$ & Leave for 1 minute & Leave for 1minute & Leave for $1 \mathrm{~min}$ \\
\hline $\begin{array}{l}\text { Rinse each slide gently } \\
\text { with clean water until } \\
\text { all excess stain has been } \\
\text { washed away }\end{array}$ & $\begin{array}{l}\text { Rinse each slide gently } \\
\text { with clean water until } \\
\text { all excess stain has been } \\
\text { washed away }\end{array}$ & Wash with water. & Wash smear slides & $\begin{array}{l}\text { Gently rinse slides with } \\
\text { water }\end{array}$ & $\begin{array}{l}\text { Wash gently in running } \\
\text { water and drain }\end{array}$ & $\begin{array}{l}\text { Cover with phenol } 5 \% \\
\text { for sterilization for } 10 \\
\text { min, then gently rinse } \\
\text { slides with water }\end{array}$ \\
\hline $\begin{array}{l}\text { Allow to dry in open air } \\
\text { but out of direct sunlight }\end{array}$ & $\begin{array}{l}\text { Allow to dry in open } \\
\text { air but out of direct } \\
\text { sunlight }\end{array}$ & $\begin{array}{l}\text { Allow to dry in } \\
\text { open air but out } \\
\text { of direct sunlight }\end{array}$ & $\begin{array}{l}\text { Allow to dry in } \\
\text { open air but out of } \\
\text { direct sunlight }\end{array}$ & $\begin{array}{l}\text { Allow to dry in open air } \\
\text { but out of direct sunlight }\end{array}$ & $\begin{array}{l}\text { Allow to dry in open } \\
\text { air but out of direct } \\
\text { sunlight }\end{array}$ & $\begin{array}{l}\text { Allow to dry in open air } \\
\text { but out of direct sunlight }\end{array}$ \\
\hline $\begin{array}{l}\text { Read the preparation } \\
\text { under the microscope } \\
\text { using the immersion lens } \\
\text { (X100) }\end{array}$ & $\begin{array}{l}\text { Read the preparation } \\
\text { under the microscope } \\
\text { using the immersion } \\
\text { lens (X100) }\end{array}$ & $\begin{array}{l}\text { Read the } \\
\text { preparation } \\
\text { under the } \\
\text { microscope } \\
\text { using the } \\
\text { immersion lens } \\
\text { (X100) }\end{array}$ & $\begin{array}{l}\text { Read the } \\
\text { preparation under } \\
\text { the microscope } \\
\text { using the } \\
\text { immersion lens } \\
\text { (X100) }\end{array}$ & $\begin{array}{l}\text { Minimum X250 } \\
\text { Fluorescent in a dark } \\
\text { room }\end{array}$ & $\begin{array}{l}\text { X400 No dark room, no } \\
\text { direct sunlight }\end{array}$ & $\begin{array}{l}\text { X } 200 \text { magnification } \\
\text { on LED fluorescence } \\
\text { microscope }\end{array}$ \\
\hline \multicolumn{7}{|c|}{ Use WHO/IUATLD Grading scale for the smears } \\
\hline Cost per test $(\$ 1.64)$ & Cost per test $(\$ 1.64)$ & $\begin{array}{l}\text { Cost per test } \\
(\$ 1.64)\end{array}$ & $\begin{array}{l}\text { Cost per test } \\
(\$ 1.64)\end{array}$ & Cost per test $(\$ 3.40)$ & $\begin{array}{l}\text { Cost per test }((\$ 1.64 \\
-\$ 2.11)\end{array}$ & Cost per test $(\$ 3.40)$ \\
\hline
\end{tabular}

This table shows the different techniques of AFB staining and the reagents used for their implementation.

modification, and was also widely adopted [15]. Tan Thiam Hok devised a method by combining the staining techniques of Kinyoun and Gabbet's [23]. This method was less laborious but also less robust. But, higher concentration of Carbolfuchsin was needed and longer staining time period as shown in Table 1.

\section{Modified schaeffer and fulton stain}

This method was developed in 1933 by Schaeffer and Fulton for staining endospores [26], and then modified by Deshmukh to stain AFB [27]. This method was found to be simple, reliable, less expensive and as efficient as Ziehl-Nielsen stain [27].

\section{Hot ziehl-neelsen method}

The Ziehl-Neelsen method is the most common laboratory technique for staining acid-fast tubercle bacilli for diagnosing pulmonary TB and this conventional method is available in most primary health-care laboratories in resource limited settings [23]. The procedure for Z-N staining is described in Table 1 [15].

\section{Staining methods using fluorescence microscopy} Replacing conventional light microscopy with fluorescence microscopy would improve TB case detection, speed up 
sputum examination, and reduce workload. Fluorescence microscopy was introduced by the National Tuberculosis Programs (NTP) in many countries, in attempt to improve outcomes of smear microscopy. However, these techniques are used by few laboratories in resource limited settings, only in specialized laboratories and not in peripheral health institutions [28].

\section{Fluorochrome acid-fast microscopy}

Fluorochrome acid-fast microscopy is easy to perform and it's currently the most rapid procedure for detecting AFB in clinical specimens [7]. Fluorochrome-stained smears can be viewed at lower magnifications. The stains are not more expensive than Carbolfuchsin stain but the limit of its use is the cost of a fluorescent microscope. It's therefore strongly recommended that suspect bacilli be confirmed at higher magnification, and that positive fluorochrome stains be confirmed by Z-N microscopy [7]. FM is more sensitive than conventional Z-N microscopy [29]. It's mainly used in industrialized countries, because it's cost effective in saving examination time to detect positive and negative smears. Sputum smears could be done from direct, pretreated, and concentrated specimens to increase sensitivity of the method. The stained smear should show a light brown or blue color $[15,25]$.

\section{Light emitting diodes microscopy (LED)}

LED microscopy was developed mainly to give resourcelimited countries access to the benefits of fluorescence microscopy. LED microscopy showed $84 \%$ sensitivity and $98 \%$ specificity against culture as the reference standard. It was $5 \%$ more sensitive and $1 \%$ more specific than conventional fluorescence microscopy [9]. On the basis of these findings, WHO recommends that conventional fluorescence microscopy be replaced by LED microscopy, and that LED microscopy be phased in as an alternative for conventional Z-N light microscopy [9]. LED fluorescence microscopy was found to work better than conventional fluorescence microscopy [30]. The LED microscope lamp is inexpensive compared to the mercury vapor (or halogen lamp) used in the fluorescent microscopy and has a long life span and it is a boon to mycobacteriologists. The cost of LED equipment is $\$ 4580$. LED fluorescence microscopy not require.

\section{Fluorescein-diacetate (FDA) vital staining}

This method was described in 1980, first for evaluating the viability of mycobacterial culture using FDA and ethidium bromide [31] and now used for AFB vitality in sputum smear. Culture is expensive and has significant requirements for human resources and sophisticated laboratory infrastructure, neither of which is readily available in resource limited settings and FDA would be a wonderful alternative for TB diagnosis in these countries. FDA is a vital staining for predicting tuberculosis culture results and treatment failure.

Treatment failure of TB is defined as a patient who is sputum smear or sputum culture positive at 5 months or later after the initiation of anti-TB treatment [3]. The main monitoring tool available in resource-limited settings for treatment monitoring remains sputum smear microscopy using Z-N or auramine staining. Recent studies proposed a simple and instant method for TB treatment monitoring, based on a common fluorescent viability marker, FDA, in combination with smear microscopy [11]. In the context with effective anti-TB treatment and low rates of primary multidrug-resistant tuberculosis (MDR-TB), excellent microscopy for AFB may lead to frequent over-diagnosis of first treatment failure, due to confusion with late excretion of dead bacilli [30]. FDA vital staining can thus greatly improve the efficiency of MDR-TB screening and diagnosis among smear-defined late converters [30]. This staining method can distinguish viable and dead bacilli in smear with the best use of LED. Vital staining with fluoresecein diacetate could stain living TB bacilli in a sputum smear, enabling them to immediately see those bacilli escaping treatment.

\section{Quality assurance in TB microscopy network}

Microscopy network of sputum smear microscopy centers for the diagnosis and monitoring of smear positive pulmonary TB is a key component in facilitating the implementation of DOTS through NTP. The quality of work in AFB diagnostic microscopy depends on a number of factors like specimen collection, quality of reagent, staining technique, reading of smear, reporting and recording, and training of technicians. Good staining reagents, especially those made with a highquality basic fuchsin dye, are essential to detect AFB. Poor quality staining reagents may not show $A F B$ and a case of TB may be missed [13].

For TB control, the main tool used by NTP in resource limited countries is the sputum-smear microscopy, particularly the hot Ziehl-Nielsen technique [15]. FDA is a hope for resource limited countries to monitor and control TB treatment and many efforts should be done to transfer in resource limited settings FDA method.

\section{Discussion}

For TB control, the main tool used by NTP in resource limited countries is the sputum-smear microscopy, particularly the hot Z-N technique. However, fluorescent microscopy introduce in some laboratories detects $10 \%$ more TB cases than optical microscopy and requires only $25 \%$ of the time taken to read a Z-N stained smear. FM requires equipment that is expensive for laboratories in resource limited settings, but it have benefits. The use of a LED light source for fluorescence microscopy brings several advantages because the same device could be used to implement the FDA method. FDA is a vital stain for predicting tuberculosis culture results and a hope for resource limited countries to monitor and control TB treatment. The main limit of this technique is the necessity to keep the reagent in freezer. Implementation of FDA methods 
to monitor tuberculosis treatment is possible with international concerted, global fund and nongovernmental organizations support. It could improve the efficiency of smear microscopy services in resource limited settings. Therefore FDA as an alternative method of culture should be considered for use in resource limited settings for TB care.

\section{Conclusion}

Transfer of FDA technique in resource limited settings can reduce the number of cases where medical personal start a retreatment because it ascertains that bacilli detected by Z-N, FM and LED in fact are dead ones, which do not require further treatment. FDA could be an efficiency tool for the rapid identification of live Mycobacterium tuberculosis among treatment failure cases in resource limited settings.

\section{Competing interests}

The authors declare that they have no competing interests.

Authors' contributions

\begin{tabular}{|l|c|c|c|}
\hline Authors' contributions & ZD & CMM & OJ \\
\hline Research concept and design & $\checkmark$ & -- & -- \\
\hline Collection and/or assembly of data & $\checkmark$ & -- & -- \\
\hline Data analysis and interpretation & $\checkmark$ & -- & -- \\
\hline Writing the article & $\checkmark$ & $\checkmark$ & $\checkmark$ \\
\hline Critical revision of the article & $\checkmark$ & $\checkmark$ & $\checkmark$ \\
\hline Final approval of article & $\checkmark$ & $\checkmark$ & $\checkmark$ \\
\hline Statistical analysis & -- & -- & -- \\
\hline
\end{tabular}

Publication history

EIC:Thimios A. Mitsiadis, University of Zurich, Switzerland. Received: 21-Dec-2013 Revised: 20-Jan-2014

Re-Received: 22-Jan-2014 Accepted: 06-Feb-2014

Published: 26-Feb-2014

\section{References}

1. Swarnlata $P$, Shoba $K$ and Khublani TK. A review on TB and its advance diagnostic techniques. International Journal of Pharma and Bio Sciences. 2011; 2:535-545. | Pdf

2. WHO. Global tuberculosis report 2012. Geneva, Switzerland: World Health Organization; 2012. I Pdf

3. Namukwaya E, Nakwagala FN, Mulekya F, Mayanja-Kizza $\mathrm{H}$ and Mugerwa R. Predictors of treatment failure among pulmonary tuberculosis patients in Mulago hospital, Uganda. Afr Health Sci. 2011; 11 Suppl 1:S105-11. | Article | PubMed Abstract | PubMed Full Text

4. Wania RLS. Tuberculosis 2: Pathophysiology and microbiology of pulmonary tuberculosis. SSMJ. 2013; 6:10-12. | Pdf

5. Chesteras M. Tuberculosis in Children and Young Adults. 1943. | Pdf

6. Ghaleb K, Afifi M and El-Gohary M. Assessment of diagnostic techniques of urinary tuberculosis. Mediterr J Hematol Infect Dis. 2013; 5:e2013034. | Article | PubMed Abstract | PubMed Full Text

7. WHO. Laboratory services in tuberculosis control.Part II. Microscopy. Geneva, Switzerland; 1998. I Pdf

8. WHO. Guidelines for intensified tuberculosis case-finding and isoniazid preventive therapy for people living with HIV in resource-constrained settings. Geneva, Switzerland; 2011. I Pdf

9. WHO. Fluorescent Light-Emitting Diode (LED) Microscopy for Diagnosis of Tuberculosis: Policy Statement. Geneva/Sweeden; 2011. I Pdf

10. Gupta S, Prasad V, Bairy I and Muralidharan S. Comparative evaluation of two cold staining methods with the Ziehl-Neelsen method for the diagnosis of tuberculosis. Southeast Asian J Trop Med Public Health. 2009; 40:765-9. | Pdf | PubMed

11. Schramm B, Hewison C, Bonte L, Jones W, Camelique O, Ruangweerayut $\mathrm{R}$, Swaddiwudhipong $\mathrm{W}$ and Bonnet $M$. Field evaluation of a simple fluorescence method for detection of viable Mycobacterium tuberculosis in sputum specimens during treatment follow-up. J Clin Microbiol. 2012; 50:2788-90. | Article | PubMed Abstract | PubMed Full Text

12. Hamid Salim A, Aung KJ, Hossain MA and Van Deun A. Early and rapid microscopy-based diagnosis of true treatment failure and MDR-TB. Int J Tuberc Lung Dis. 2006; 10:1248-54. | Article I PubMed

13. IUATLD.Technical Guidet. Sputum examination for tuberculosis by direct microscopy in low income countries. Ottawa/Canada: International Union Against Tuberculosis and Lung Disease. 2000. | Pdf

14. Somoskovi A, Hotaling JE, Fitzgerald M, O'Donnell D, Parsons LM and Salfinger M. Lessons from a proficiency testing event for acid-fast microscopy. Chest. 2001; 120:250-7. | Article | PubMed Abstract | PubMed Full Text

15. Rieder HL, Deun AV, Kam KM, Kim SJ, Chonde TM and Trébucq A et al. Priorities for Tuberculosis Bacteriology Services in Low-Income Countries. Second ed. Paris/France: International Union Against Tuberculosis and Lung Disease. 2007. I Book

16. Zingue D, Hien H, Meda N, Zida S, Kabore A, Sanou A, Ouedraogo AS, Gomgnimbou M, Diande S, Tarnagda Z and Godreuil S. [Advantages and drawbacks of expectoration decontamination methods for tuberculosis and anti-tuberculosis drug resistance diagnosis]. Ann Biol Clin (Paris). 2013; 71:283-91. | Article | PubMed

17. WHO. Tuberculosis laboratory biosafety manual. Geneva/Switzerland; 2012. I Pdf

18. Manual for Sputum Smear Fluorescence Microscopy. New Dehli: Central TB Division. I Pdf

19. WORLD HEALTH ORGANIZATION. Toman's Tuberculosis-Case Detection, Treatment and Monitoring: Questions and Answers. 2nd ed. Geneva, Switzerland: WHO; 2004. I Pdf

20. Long R, Scalcini M, Manfreda J, Jean-Baptiste M and Hershfield E. The impact of HIV on the usefulness of sputum smears for the diagnosis of tuberculosis. Am J Public Health. 1991; 81:1326-8. | Article | PubMed Abstract | PubMed Full Text

21. Githui W, Nunn P, Juma E, Karimi F, Brindle R, Kamunyi R, Gathua S, Gicheha C, Morris J and Omwega M. Cohort study of HIV-positive and HIV-negative tuberculosis, Nairobi, Kenya: comparison of bacteriological results. Tuber Lung Dis. 1992; 73:203-9. | Article | PubMed

22. WHO. Tuberculosis prevalence surveys: a handbook. Geneva, Switzerland; 2011. I Pdf

23. Vasanthakumari $R$, Jagannath $K$ and Rajasekaran $S$. A cold staining method for acid-fast bacilli. Bull World Health Organ. 1986; 64:741-3. | PubMed Abstract | PubMed Full Text

24. Van Deun A, Hamid Salim A, Aung KJ, Hossain MA, Chambugonj N, Hye MA, Kawria A and Declercq E. Performance of variations of carbolfuchsin staining of sputum smears for AFB under field conditions. Int J Tuberc Lung Dis. 2005; 9:1127-33. | Article | PubMed

25. Gupta S, Shenoy VP, Bairy I and Muralidharan S. Comparison among three cold staining methods in the primary diagnosis of tuberculosis: a pilot study. J Bras Pneumol. 2010; 36:612-6. I Article I PubMed

26. Schaeffer $A B$ and Fulton MD. A Simplified Method of Staining Endospores. Science. 1933; 77:194. | Article I PubMed

27. Deshmukh SR, Mantri SB, Kendre PB and Nagoba BS. A comparison of sputum examination for acid fast bacilli by modified Schaeffer \& Fulton stain, Ziehl-Neelsen stain \& cold stain. Indian J Med Res. 1996; 103:2945. | Article | PubMed

28. Das D and Selvakumar N. Can LED fluorescence microscopy replace Ziehl-Neelsen microscopy in tuberculosis detection? Int J Tuberc Lung 
Dezemon et al. Trends in Bacteriology 2014,

Dis. 2012; 16:1558. | Article | PubMed

29. Desikan P. Sputum smear microscopy in tuberculosis: is it still relevant? Indian J Med Res. 2013; 137:442-4. | Article | PubMed Abstract | PubMed Full Text

30. Van Deun A, Maug AK, Hossain A, Gumusboga M and de Jong BC. Fluorescein diacetate vital staining allows earlier diagnosis of rifampicin-resistant tuberculosis. Int J Tuberc Lung Dis. 2012; 16:1174-9. | Article | PubMed

31. Jarnagin JL and Luchsinger DW. The use of fluorescein diacetate and ethidium bromide as a stain for evaluating viability of mycobacteria. Stain Technol. 1980; 55:253-8. | Article | PubMed

\section{Citation:}

Dezemon Z, Muvunyi CM and Jacob O. Staining techniques for detection of acid fast bacilli: what hope does fluorescein-diacetate (FDA) vitality staining technique represent for the monitoring of tuberculosis treatment in resource limited settings. Trends Bacteriol. 2014; 1:1.

http://dx.doi.org/10.7243/2057-4711-1-1 